\title{
Bioindication of water pollution of Lake Sevan freshwater ecosystem (Armenia) using model test-object
}

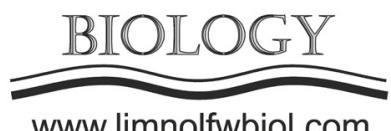

www.limnolfwbiol.com

\author{
Aghajanyan E.A., Avalyan R.E.*, Atoyants A.L., Aroutiounyan R.M. \\ Laboratory of General and Molecular Genetics, RI "Biology", Faculty of Biology, Yerevan State University, 8, Charents Str., 0025, \\ Yerevan, Armenia
}

\begin{abstract}
For the past years, in Armenia water resources (Lake Sevan) have been affected by intensive anthropogenic impact. The process of bioindication of freshwater ecosystems genotoxic effects using sensitive test objects is very appropriate and effective. We have investigated the genotoxic and clastogenic effects of water samples in seven locations of the Lake Sevan basin (Armenia) using Trad-SHM (stamen hair mutation) and Trad-MCN (micronuclei in tetrads of microspores) bioassays using Tradescantia (clone 02). The study has revealed a significant increase in the frequency of somatic recessive mutations and increased amount of micronuclei in tetrads and tetrads with micronuclei in microspores of the plants submerged in the water collected off the Tsapatagh, Litchk and Martuni settlements, compared to the control plants. We show the significant positive correlation between the RME frequency and the concentration of some chemical elements $(\mathrm{Si}, \mathrm{P}, \mathrm{Al}, \mathrm{Mn}, \mathrm{Fe}$, and $\mathrm{Cu})$ in the studied water samples. We also show the positive correlation between tetrads with micronuclei frequency and the concentration of $\mathrm{Ni}$ and $\mathrm{Co}$ in the investigated water samples.
\end{abstract}

Keywords: Tradescantia (clone 02), water pollution, freshwater ecosystem, genotoxicity, clastogenicity

\section{Introduction}

The pollution of freshwater resources has presently acquired a global nature. Any changes in the composition of water have a direct impact on all the activity processes of water organisms. Current levels of anthropogenic stress on freshwater resources force to periodically evaluate water quality and the health of hydroecosystems. The water resources of Armenia have been affected by intensive anthropogenic impact. Lake Sevan, one of the largest and most exploited alpine limnosystems in the world, playing a unique role in the economic development of Armenia (Fig. 1). The lake is fed by 28 rivers that drain residential, agricultural and industrial areas. The use of water from Lake Sevan considerably improved the condition of industry and agriculture in the country. In the pollution of Lake Sevan, much role belongs to a sharp increase in the inflow of polluting and toxic substances of technogenic origin from the lake basin (Hovhannissyan, 1994; Matishov et al., 2016).

Despite the economic development, the state of the lake's basin is deteriorated. Nevertheless, biotesting of the state of the lake ecosystem has been limited to monitoring the chemical composition of the water and biomonitoring using sensitive model test-system.
(Steinkellner et al., 1999; Ma et al., 2005) The process of bioindication of genotoxic effects of complex mixtures on the water resources using plants test-objects is very appropriate and effective. Test-systems based on plant use have shown high sensitivity and are recommended for monitoring genotoxicity of xenobiotics in the air, water and soil (Grant, 1994; Ma, 1999; Aghajanyan et al., 2015). Among plants test-objects, the heterozygote clones for flower color (blue-dominant, pink-recessive) of Tradescantia (clones 02 and 4430) plays a special role. The Tradescantia stamen hair mutation (Trad-SHM) and Tradescantia-micronucleus (Trad-MCN) bioassays are the efficient and reliable biomonitoring test-systems for detecting the genotoxicity and clastogenic effects of environmental pollutants (Ma et al., 2005; Majer et al., 2005; Mizik et al., 2011; Avalyan et al., 2017). These bioassays are included in the International Program on Plant Bioassay (IPPB) under the auspies of The United Nations Environment Programme (UNEP) (Ma, 1999).

The aim of this study was to assess the genotoxicity and clastogenicity of water from different parts of the Lake Sevan basin, Armenia by Trad-SHM and Trad-MCN assays using Tradescantia (clone 02). The Trad-SHM and Trad-MCN assays were simultaneously used to determine the genetic effects of the investigated water samples. 


\section{Material and methods}

\section{Sampling sites}

Water samples were collected at three times in different periods from seven locations of the Lake Sevan basin, Armenia: off the Artanish, Karchaghbyur, Tsapatagh, Noradus, Litchk, Masrik, and Martuni settlements (Fig. 2). The samples were collected at a depth of approximately $30 \mathrm{~cm}$ in three replicates per sampling site in $1 \mathrm{~L}$ pre-cleaned plastic bottles. Samples were stored at $+4^{\circ} \mathrm{C}$ until delivery to the laboratory. Tests were initiated on the next day.

\section{Tradescantia (clone 02)}

Tradescantia (clone 02) used for this study was obtained from the greenhouse of Yerevan State University. It is an interspecific hybrid between Tradescantia occidentalis Briffon ex Ridb. and T. ohiensis Raf. (Fig. 3). This clone is heterozygous for flower color (blue/pink, the pink color being recessive). For Tradescantia stamen hair mutation bioassay (Trad-SHM), the appearance of pink cells of stamen hair (recessive mutation events - RME) was a marker criterion. In addition, during testing there were morphological changes in stamen hairs, dwarf (non-surviving NS) and branching hairs (BH). Using micronucleus bioassay (Trad-MCN) two main test criteria were counted: percentage of micronuclei in tetrads and percentage of tetrads with micronuclei.

\section{Trad-SHM assay}

The assay was based on counting somatic mutations and morphological changes that could be indicators of genotoxic or teratogen effects of Tradescantia (clone 02).

For testing, young inflorescences were submerged in water samples (three-five inflorescences for vessel per variant) for $24 \mathrm{~h}$, and after a seven-day recovery period, flower blossoms were examined. Stamen hairs of a flower were placed on a slide and observed under a magnifying glass at $10 \mathrm{x}$ for counting blue to pink mutation and morphological changes. Flowers were examined daily over 21 days since their appearance. From 8000-14000 stamen hairs were obtained per sample. The number of mutations per sample was calculated per 1000 hairs according to standard protocols (Ma et al., 1994a). Tap water was used as a control, and test vessels were set in triplicate.

\section{Trad-MCN assay}

The assay was based on the scoring of the micronuclei (MCN) frequency in pollen mother cells at disturbances in the process of microsporogenesis (Ma et al., 1994b; Mizik et al., 2011). Formation of micronuclei is related to chromosomal instability and is indicative of genomic damage.

For testing, young inflorescences of Tradescantia were also submerged into the test water samples. The duration of treatment was $24 \mathrm{~h}$. The inflorescences were removed and fixed in Carnoy's solution (3:1 ethanolglacial acetic acid). Preparation of the tetrads and the scoring of the micronuclei were carried out as described

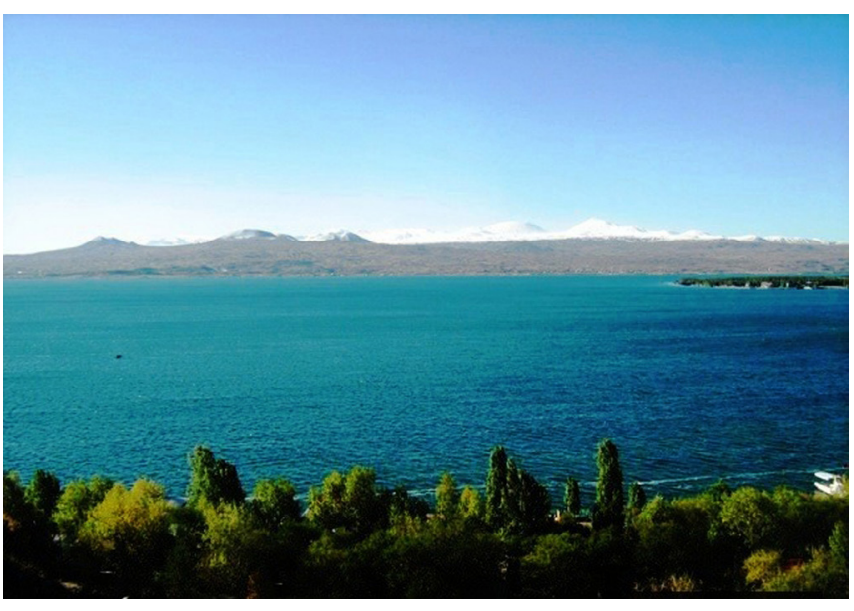

Fig.1. Lake Sevan

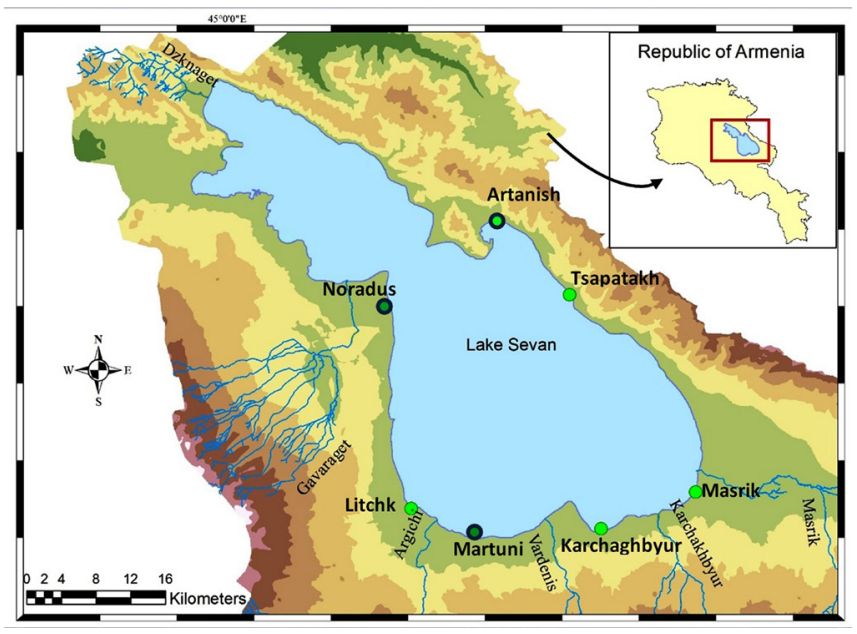

Fig.2. Water sampling stations on Lake Sevan

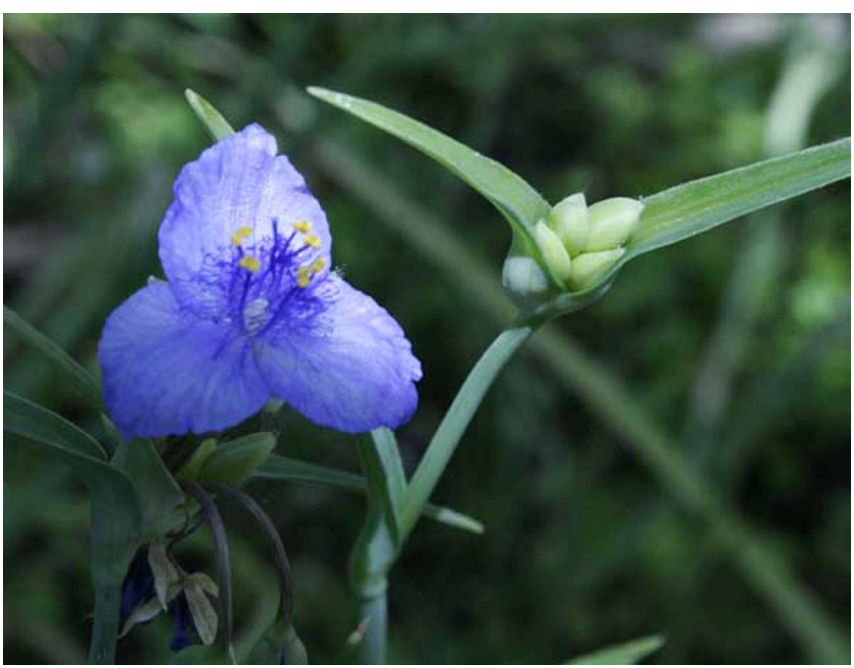

Fig.3. Tradescantia (clone 02) 
in Ma et al. (1994b). The following test criteria were used: the number of tetrads with micronuclei (Tetr/ $\mathrm{MCN}$ ) and the number of micronuclei per 100 tetrads (MCN/tetr). For each water sample, 3000 tetrads were analyzed.

\section{Chemical and statistical analysis}

Water samples were analyzed for chemical composition at a certified laboratory, following standard methods (Standard methods..., 1998). Several elements were measured (total concentrations): $\mathrm{Al}, \mathrm{Ni}$, $\mathrm{Zn}, \mathrm{As}, \mathrm{Cu}, \mathrm{Fe}, \mathrm{Cr}, \mathrm{Co}, \mathrm{Mo}, \mathrm{Cd}, \mathrm{Sn}, \mathrm{Pb}, \mathrm{Mg}, \mathrm{Mn}, \mathrm{Na}$, $\mathrm{Ca}$, and $\mathrm{K}$ (Table 1). At all sites, the $\mathrm{pH}$ level varied from 8.6 to 8.7 . Chemical data were compared to the legislated water quality standards for aquaculture (from the Environmental Impact Monitoring Center of the Ministry of Nature Protection of Armenia (www. armmonitoring.am)).

All results were statistically processed using the Student $t$-test and Pearson correlation test by the computer program Statgraphics Centurion 16.2. Pearson correlation test was performed to analyze the correlation between the level of somatic mutation and the percentage of MCN as well as the concentrations of various elements and heavy metals in the studied water samples.

\section{Results and discussion}

The results of bioassay Trad-SHM have revealed a significant increase in the level of recessive mutation events (RME) frequency by water samples collected off the Noradus, Litchk, Tsapatagh, and Martuni settlements compared to the control. There is the positive correlation between the RME frequency and the concentration of some chemical elements ( $\mathrm{P}, \mathrm{Si}, \mathrm{Al}$, $\mathrm{Mn}, \mathrm{Fe}$, and $\mathrm{Cu}$ ) in the studied water samples (Table 2).

The study of clastogenic effects in the sporogenic cells of Tradescantia has also shown an increase in the occurrence frequency of both test criteria in all studied water variants compared to the control level. The water samples collected off the Litchk, Tsapatagh, Martuni, and Masrik settlements show the maximum manifestation of these genetic effects from both investigated parameters. There is a significant positive correlation between the frequency of tetrads with $\mathrm{MN}$ and the concentration of $\mathrm{Ni}$ and $\mathrm{Co}$ in the studied variants.

The obtained results have shown that the significant increase in the level of recessive mutations and clastogenic effects in the studied water samples indicates the contamination of the water in the Lake Sevan basin at the tested sites near settlements with various kinds of xenobiotics (heavy metals, pesticides, etc.) as well as their influence on the processes occurring in the somatic and generative cells of Tradescantia.

A chemical mixture of metals is more toxic than individual metals if their action is synergistic. On the other hand, the antagonistic effects of some metals in a mixture diminish the uptake of individual metals e.g., by competing for the same uptake sites at the cell surface. The toxicity of a mixture, however, depends not only on the exposure concentration of each mixture constituent and its ratio but also the means of the toxicants to act jointly (Altenburger et al., 2004). Moreover, effects may be observed at concentrations far below those predicted to be safe by regulatory frameworks (Garcia et al., 2011; Liess et al., 2016). Various authors stated that it is very important to assess the genotoxicity of contaminants in the entire environmental water sample, but not for each component. The identification of toxicants in complex mixtures realized by exposure information about biological effects and approaches that deal with complex contamination typically reveals not only individual toxicants. Thus, since the lake samples used in this study are a complex mixture, we can legitimately assume the collective effect of not only individual metals even at low concentrations.

\section{Conclusion}

According to the results of our studies, the increased frequency of MCN and the elevated pink mutation (RME) rate in the Tradescantia inflorescence are indicators of clastogenicity and mutagenicity resulting from exposure to environmental pollutants. The use of both bioassays (Trad-SHM and Trad-MCN) may be effective for biotesting the water quality

Table 1. Total concentrations of chemicals in different parts of Lake Sevan

\begin{tabular}{|l|c|c|c|c|c|c|c|c|c|c|c|c|c|c|c|c|c|}
\hline & $\mathrm{Na}$ & $\mathrm{Mg}$ & $\mathrm{Al}$ & $\mathrm{P}$ & $\mathrm{K}$ & $\mathrm{Ca}$ & $\mathrm{V}$ & $\mathrm{Cr}$ & $\mathrm{Mn}$ & $\mathrm{Fe}$ & $\mathrm{Co}$ & $\mathrm{Ni}$ & $\mathrm{Cu}$ & $\mathrm{Zn}$ & $\mathrm{As}$ & $\mathrm{Mo}$ & $\mathrm{Pb}$ \\
\cline { 2 - 3 } & \multicolumn{10}{|c|}{$\mathrm{mg} \mathrm{L}^{-1}$} \\
\hline Artanish & 47.8 & 41.7 & 0.05 & 0.3 & 14.8 & 18.4 & 5 & 20 & 0.7 & 5 & 0.1 & 2 & 1 & 0.7 & 8 & 5 & 0.0 \\
Karchaghbyur & 72.9 & 58.4 & 0.1 & 0.1 & 19.4 & 25.1 & 8 & 30 & 1 & 460 & 0.1 & 3 & 3 & 7 & 9 & 7 & 0.1 \\
Noradus & 48.6 & 41.9 & 0.07 & 0.1 & 15.1 & 18.9 & 5 & 20 & 0.2 & 70 & 0.1 & 2 & 2 & 0.7 & 8 & 5 & 0.04 \\
Masrik & 40.6 & 36.1 & 0.04 & 0.04 & 13.6 & 21.6 & 5 & 20 & 0.2 & 60 & 0.1 & 3 & 1 & 0.2 & 9 & 5 & 0.03 \\
Tsapatakh & 61.8 & 52.8 & 0.09 & 0.2 & 20.2 & 23.9 & 7 & 20 & 0.7 & 190 & 0.1 & 3 & 2 & 0.6 & 10 & 5 & 0.0 \\
Litchk & 38 & 30 & 0.12 & 0.08 & 11.5 & 16.1 & 7 & 20 & 1 & 70 & 0.1 & 1 & 0.6 & 0.3 & 8 & 2 & 0.2 \\
Martuni & 8.5 & 5.8 & 0.0 & 0.0 & 2.0 & 12.9 & 5 & 7 & 1 & 70 & 0.1 & 1 & 1 & 0.5 & 4 & 4 & 0.5 \\
Control & 8.47 & 5.83 & 0.0 & 0.0 & 1.96 & 12.9 & 23 & 7.6 & 1.1 & 8.6 & 0.0 & 1.7 & 1.1 & 64 & 3.8 & 2.3 & 0.1 \\
\hline
\end{tabular}


Table 1. Induction of genotoxic and clastogenic effects of Tradescantia (clone 02)

\begin{tabular}{|l|c|c|c|}
\hline \multirow{2}{*}{ Sampling sites } & \multirow{2}{*}{$\begin{array}{c}\text { Frequency } \\
\text { of RME/ 1000 }\end{array}$} & \multicolumn{2}{|c|}{ Frequency of micronuclei in sporogenic cells } \\
\cline { 3 - 4 } & Tetrads with MCN (\% \pm SD) & MCN in tetrads (\% \pm SD) \\
\hline 1. Artanish & $0.8 \pm 0.31^{*}$ & $3.4 \pm 0.33^{* * *}$ & $4.2 \pm 0.36^{* * * *}$ \\
2. Karchaghbyur & $0.7 \pm 0.28^{*}$ & $5.2 \pm 0.40^{* * *}$ & $6.5 \pm 0.45^{* * * *}$ \\
3. Noradus & $1.8 \pm 0.44^{* * *}$ & $5.5 \pm 0.41^{* * *}$ & $7.0 \pm 0.46^{* * * *}$ \\
4. Masrik & $0.7 \pm 0.29^{*}$ & $8.3 \pm 0.50^{* * *}$ & $11.7 \pm 0.58^{* * * *}$ \\
5. Tsapatagh & $1.2 \pm 0.29^{* * *}$ & $6.0 \pm 0.43^{* * *}$ & $7.7 \pm 0.48^{* * * *}$ \\
6. Litchk & $1.6 \pm 0.34^{* * *}$ & $6.0 \pm 0.43^{* * * *}$ & $7.4 \pm 0.47^{* * * *}$ \\
7. Martuni & $1.2 \pm 0.29^{* * *}$ & $6.2 \pm 0.44^{* * * *}$ & $7.4 \pm 0.47^{* * * *}$ \\
Control & $0.2 \pm 0.14$ & $1.8 \pm 0.24$ & $2.4 \pm 0.28$ \\
\hline
\end{tabular}

$*-\mathrm{p}<0.05, * *-\mathrm{p}<0.01, * * *-\mathrm{p}<0.001$

and allows assessing the potential risk of aquatic contaminants of the natural hydroecosystem of Lake Sevan.

\section{References}

Avalyan R.E., Aghajanyan E.A., Khosrovyan A. et al. 2017. Assessment of mutagenicity of water from Lake Sevan, Armenia with application of Tradescantia (clone 02). Mutation Research 800: 8-13. DOI: 10.1016/j.mrfmmm.2017.03.006

Aghajanyan E.A., Avalyan R.E., Atoyants A.L. et al. 2015. A study of genetic effects in natural ecosystems using a plant test object. Trudy po Prikladnoy Botanike, Genetike i Selektsii [Works on Applied Botany, Genetics and Selection] 176: 346-356. (in Russian).

Altenburger R., Walter H., Grote M. 2004. What contributes to the combined effect of a complex mixture? Environmental Science Technology 38: 6353-6362. DOI: 10.1021/es049528k

Garcia A.C.F.S., Marcon A.E., Ferreira D.M. et al. 2011. Micronucleus study of the quality and mutagenicity of surface water from a semi-arid region. Journal of Environmental Monitoring 13: 3329-3335. DOI: 10.1039/c1em10582e

Grant W.F., Lee H.G., Logan D.M. et al. 1992. The use of Tradescantia and Vicia faba bioassays for the in situ detection of mutagens in an aquatic environment. Mutation Research 270: 53-64. DOI: 0027-5107/92/S05.00

Grant W.F. The present status of higher plant bioassay for the detection of environmental mutagens. 1994. Mutation Research 310: 175-185. DOI: 10.1016/0027-5107(94)90112-0

Hovhannisyan R.H. 1994. Lake Sevan yesterday, today ... Yerevan. (in Russian)

Liess M., Foit K., Knillmann S. et al. 2016. Predicting the synergy of multiple stress effects. Scientific Reports 6. DOI: $10.1038 /$ srep32965
Ma T.H., Cabrera G.L., Cebulska-Wasilevska A. et al. 1994a. Tradescantia stamen hair mutation bioassay. Mutation Research 310: 211-220. DOI: 0027-5107/94//S07.00

Ma T.H., Cabrera G.L., Chen R. et al. 1994b. Tradescantia micronucleus bioassay. Mutation Research 310: 220-230. DOI: 0027-5107/94//S07.00

Ma T.H. 1999. The international program on plant bioassay collaborative studies with plant systems. Mutation Research 426: 96-97. DOI: S0027-5107(99(00047-0

Ma T.H., Cabrera G.L., Owens E. 2005. Genotoxic agents detected by plant bioassays. Reviews on Environmental Health 20: 1-13. DOI: 10.1515/REVEH.2005.20.1.1

Majer B.J., Grummi T., Uhl M. et al. 2005. Use of plant bioassay for the detection of genotoxins in the aquatic environment. Acta Hydrochimica et Hydrobiologica 33: 45-55. DOI: S1383-5718(02)00004-9

Matishov G.G., Selyutin V.V., Mesropyan K.E. et al. 2016. Current state and problems of the study of Lake Sevan. Nauka Yuga Rossii [Science in the South of Russia] 12: 43-52. (in Russian)

Mizik M., Ma T.H., Nersesyan A. et al. 2011. Micronucleus assays with Tradescantia pollen tetrads: an update. Mutagenesis 26: 215-221. DOI: 10.1093/mutage/geq080

Standard methods for the examination of water and wastewater. 1998. In: Rice E.W., Baird R.B., Eaton A.D. (Eds.). Washington: American Public Health Association.

Steinkellner H., Kassie F., Knasmuller S. 1999. Tradescantia-micronucleus assay for assessment of the clastogenicity of Austrian water. Mutation Research 426: 113-116. DOI: S0027-5107(99)00051-2

Yang G. 1999. Tradescantia-micronucleus assay on the water quality of Lake Hongzhe in Jiangsu Province, China. Mutation Research 426: 155-157. DOI: S0027-5107(99)00060-3 